\title{
ТАМСАГБУЛАГ, ЦАГААН ЭЛСНИЙ ОРДЫН ГАЗРЫН ТОСОНД АГУУЛАГДАХ МИКРОЭЛЕМЕНТИЙГ ИНДУКЦИЙН ХОЛБООТ ПЛАЗМТ ОПТИК ЭМИССИЙН СПЕКТРОМЕТРИЙН АРГААР СУДЛАХ НЬ
}

\author{
Ж.Сайнбаяр, А.Сайнбаяр, Г.Сүхдорж, Д.Монхообор
} МУИС, Химийн фракультет, monkhbr@yahoo.com

\section{Хураангуй}

Тамсагбулаг, Цагаан Элсний ордын газрын тосонд агуулагдах микроэлементийн агуулгыг Индукцийн холбоот плазмт оптик эмиссийн спектрометр (ИХПОЭС)-ийн аргаар судалж 30 гаруй микроэлементийг 0.00135.8 саяны хэсэг (с.х.) агуулгатайгаар илрүүлсэн бөгөөд тэдгээрийн дотор иттри, лантан, сканди, кадми, берилли, инди зэрэг ховор элементүүд 0.033.07 c.х. хэмжээтэйгээр агуулагдаж байгааг тогтоов. Газрын тосонд агуулагдах ванадий:никель (V:Ni)-ийн харьцаа Тамсагбулаг, Цагаан Элсний ордын хувьд 0.09-0.50 байгаа нь мезозойн болон гуравдагч үеийн насжилттай чулуулагт агуулагдах газрын тос байж болох юм.

$\mathrm{Be}, \mathrm{Bi}, \mathrm{Cd}, \mathrm{Mo}, \mathrm{Ni}, \mathrm{W}, \mathrm{Zn}$ зэрэг элементүүд Тамсагбулагийн ордын газрын тосонд их, Al, Ca, Co, Fe, In, Mg, Mn, Na, Si, Sr, V, Sn зэрэг элементүүд нь Цагаан Элсний ордын газрын тосонд их хэмжээтэй агуулагдаж байна. Өөрөөр хэлбэл газрын тосны нягт, хүхрийн агуулга ихсэхэд $\mathrm{Al}, \mathrm{Ca}, \mathrm{Co}, \mathrm{Fe}, \mathrm{In}, \mathrm{Mg}, \mathrm{Mn}$, $\mathrm{Na}, \mathrm{Si}, \mathrm{Sr}, \mathrm{V}, \mathrm{Sn}$ зэрэг элементүүдийн агуулга ихэсдэг зүй тогтол ажиглагдаж байна.

Түлхүур үг: Газрын тос, микроэлемент, Индукцийн холбоот плазмт оптик эмиссийн спектрометри (ИХПОЭС-ийн арга), мезозой, палеозой, гуравдагч үеийн насжилт.

\section{Оршил}

Судлаачид Монгол орны газрын тос, түүний фрракцуудын фризик-хими, хими технологийн шинж чанар, хүхэр органик нэгдлийн төрөрл агуулгыг нэлээд судалсан [1] боловч микроэлементийн нарийвчилсан судалгаа хийгдээгүй байна.

Эрдэмтдийн судалгаагаар газрын тосонд 30 орчим металл, 20 гаруй металл биш агуулагддаг болохыг тогтоожээ [2,3]. Анх микроэлементийн 
судалгааг геохимичидхийсэн бөгөөдгазрын тосны микроэлементийн найрлага нь газрын тосны насжилт, үүсч тогтсон хэлбэр, шилжилт, үүсэл гарлын талаар геохимийн мэдээлэлд чухал үүрэг гүйцэтгэдэг [4-8]. Газрын тосонд агуулагдах микроэлементийг тодорхойлон дараах хэд хэдэн чиглэлээр ашиглаж байна. 1. Газрын тосны гарал үүсэл, насжилт, нөөц, миграцийн талаар өгөх геологигеохимийн мэдээлэлд ашиглах [3,8]. 2. Ховор үнэт металлуудын (V, Ni... гэх мэт) түүхий эд болгон ашиглах $[9,10] .3$. Зарим микроэлемент нь газрын тос хадгалах сав, тоног төхөөрөмжийг зэврүүлдэг учраас газрын тос хадгалах сав тоног төхөөрөмжийн материалыг сонгох $[10,11]$. 4. Газрын тосыг боловсруулах үед түүнд агуулагдах микроэлементүүд боловсруулалтын катализаторуудыг хордуулдаг. Ийм учраас газрын тосны микроэлементүүдийг урьдчилан тодорхойлж бүтээгдэхүүний боловсруулалтын технологийг төлөвлөх $[10,13,18]$. 5. Зарим микроэлементүүд (As, Cd, Hg, Ni, S, V, Zn зэрэг) нь үйлдвэрлэсэн газрын тосны бүтээгдэхүүнд тодорхой хэмжээгээр агуулагдаж газрын тосны бүтээгдэхүүнүүдийг ашиглах явцад байгаль орчин болон амьд организмуудыг хордуулдаг учраас түүнд хяналт тавих шаардлагатай болдог $[11,12]$.

Дээрх олон шалтгаанаас Монгол орны газрын тосонд агуулагдах микроэлементүүдийг тодорхойлон түүнд үнэлгээ өгөх шаардлагатай байна.

\section{Судалгааны дээж, арга зүй}

Энэхүу судалгаанд Тамсагбулагийн XIX талбайн 13, 21, 34, 40, 2550, В 27-42-р Цагаан Элсний ТЕ 27-5, ТЕ 14-19-р цооногуудаас 2008 оны 7 сард авсан газрын тосны дээжийг ашигласан. Дээж авсан газрын тосны цооногуудын байршилыг 1-р зурагт үзүүлэв.

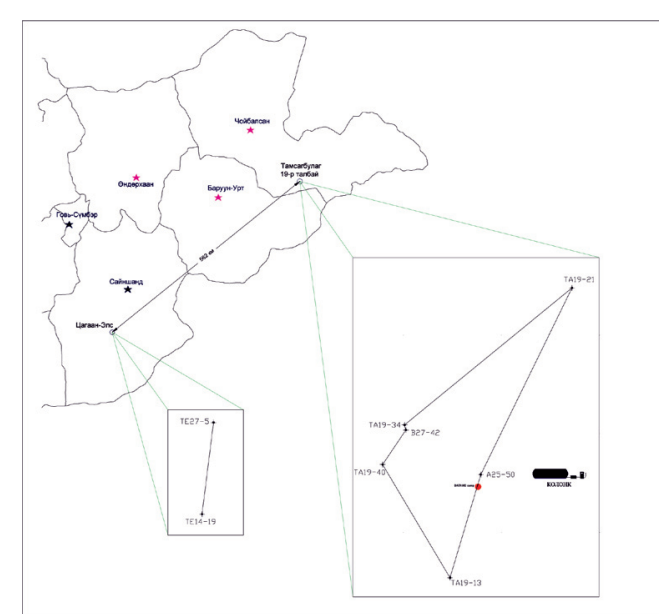

1-р зураг. Газрын тосны цооногуудын байршил 
Судалгаанд авсан Тамсагбулаг, Цагаан Элсний газрын тосны орд нь хоорондоо 560 гаруй км зайтай байна.

Судалгаанд авсан 8 дээжний нягт, хүхрийн агуулгийг тодорхойлон газрын тос илэрсэн цооногийн гүний хамт 1-р хүснэгтэнд үзүүлэв.

Тамсагбулаг, Цагаан Элсний ордын газрын тос

1-р хүснэгт илэрсэн цооногийн гүн, нягт, хүхрийн агуулга

\begin{tabular}{|c|c|c|c|c|}
\hline \multicolumn{2}{|c|}{ Газрын тосны цооног } & $\begin{array}{c}\text { Цооногийн гүн, } \\
(\text { м })\end{array}$ & $\begin{array}{c}2{ }^{\circ} \mathrm{C} \text { дахь нягт } \\
\left(г / \mathrm{cm}^{3}\right)\end{array}$ & $\begin{array}{c}\text { Хүхрийн агуулга, } \\
\%\end{array}$ \\
\hline \multirow{4}{*}{$\begin{array}{c}\text { Тамсагбулагийн XIX } \\
\text { талбайн }\end{array}$} & $21-p$ & 2625 & 0.8331 & 0.16 \\
\cline { 2 - 5 } & $13-p$ & 2311.5 & 0.8444 & 0.17 \\
\cline { 2 - 5 } & $25-50-p$ & 2630 & 0.8349 & 0.15 \\
\cline { 2 - 5 } & $27-42-p$ & 1920 & 0.8612 & 0.12 \\
\cline { 2 - 5 } & $34-p$ & 2110 & 0.8432 & 0.15 \\
\hline \multirow{2}{*}{ Цагаан Элсний } & $40-p$ & 2220 & 0.8504 & 0.11 \\
\cline { 2 - 5 } & TE 27-5-p & 1520 & 0.8799 & 0.18 \\
\hline
\end{tabular}

Тамсагбулагийн газрын тос илэрсэн цооногийн гүн нь 1920-2630 км, нягт нь 0.8331-0.8504 г/см³ хүхрийн агуулга нь 0.11-0.17\%, харин Цагаан Элсний ордын газрын тос илэрсэн цооногийн гүн 1400-1520 км, нягт нь 0.8799-0.8916

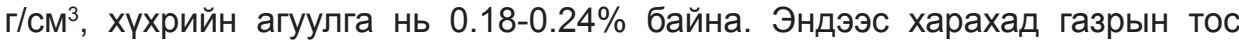
илэрсэн цооногийн гүн ихсэх тусам нягт, хүхрийн агуулга багасаж байна.

Индукцийн холбоот плазмтай оптик эмиссийн спектрометрээр Тамсагбулаг, Цагаан Элсний газрын тосны микроэлементийг тодорхойлохдоо газрын тосны дээж болон тосон стандарт уусмалаас тус бүр 2 граммыг жинлэн авч "ConostanSolve" өндөр цэвэршилттэй керосиноор 10 дахин шингэлсэн $[14,15]$. Судалгааны дээжний микроэлементийг бэлтгэсэн тосон стандарт уусмалтай харьцуулах замаар тодорхойлсон.

ИХПОЭС-ээр шинжилгээ хийх үеийн параметрийг дараах байдлаар сонгосон [16]. Үүнд: RF чадал 1500Bт, плазмын урсгал 16 л/мин, туслах урсгал 0.7 л/мин, шүрших урсгал 0.6 л/мин, инжекторын диаметр 0.8мм, ноцоогуурын байрлал -3 .

Үр дүн, хэлэлцүүлэг.

Тамсагбулагийн XIX талбайн 13, 21, 34, 40, 25-50, В 27-42-р Цагаан Элсний TE 27-5, TE 14-19-р цооногуудаас авсан газрын тосны микроэлементийг ИХПОЭС-ээр тодорхойлсон үр дүнг 2, 3-р хүснэгтэнд үзүүлэв. 
Тамсагбулагийн ордын газрын тосонд

агуулагдах микроэлементийн дундаж агуулга, с.х

\begin{tabular}{|c|c|c|c|c|c|c|c|c|}
\hline \multirow{2}{*}{ № } & \multirow{2}{*}{$\begin{array}{c}\text { Элемен- } \\
\text { түүд }\end{array}$} & \multicolumn{6}{|c|}{ Цооногууд } & \multirow{2}{*}{ Дундаж } \\
\hline & & $21-p$ & $13-p$ & $25-50-p$ & B-27-42-p & 40-p & $34-p$ & \\
\hline 1. & $\mathrm{Ag}$ & 0.1 & 0.09 & 0.11 & 0.10 & 0.10 & 0.08 & 0.096 \\
\hline 2. & $\mathrm{Al}$ & 0.28 & 0.08 & 0.91 & 0.12 & 0.74 & 0.07 & 0.36 \\
\hline 3. & B & 4.03 & 3.12 & 5.8 & 1.58 & 2.24 & 0.52 & 2.88 \\
\hline 4. & $\mathrm{Ba}$ & $<0.004$ & $<0.004$ & $<0.004$ & $<0.004$ & $<0.004$ & 0.08 & 0.018 \\
\hline 5. & $\mathrm{Be}$ & 0.1 & 0.02 & 0.01 & 0.18 & $<0.001$ & $<0.001$ & 0.051 \\
\hline 6. & $\mathrm{Bi}$ & 0.4 & $<0.001$ & $<0.001$ & 0.41 & $<0.001$ & 0.37 & 0.196 \\
\hline 7. & $\mathrm{Ca}$ & 0.151 & 1.09 & 2.04 & 0.98 & 1.97 & 1.8 & 1.338 \\
\hline 8. & $\mathrm{Cd}$ & 2.51 & 2.95 & 1.27 & 1.06 & 1.11 & 1.02 & 1.652 \\
\hline 9. & Co & $<0.001$ & $<0.001$ & $<0.001$ & 0.17 & 0.12 & 0.16 & 0.075 \\
\hline 10. & $\mathrm{Cr}$ & 0.32 & 1.09 & 1.25 & 1.17 & 0.92 & 2.17 & 1.15 \\
\hline 11. & $\mathrm{Cu}$ & 2.88 & 1.02 & 1.55 & 0.01 & 2.05 & $<0.001$ & 1.25 \\
\hline 12. & $\mathrm{Fe}$ & 0.90 & 0.46 & 1.06 & 1.26 & 0.5 & 1.3 & 0.914 \\
\hline 13. & La & 0.34 & 0.28 & 0.29 & $<0.001$ & $<0.001$ & $<0.001$ & 0.15 \\
\hline 14 & $\mathrm{Li}$ & $<0.0001$ & $<0.0001$ & $<0.0001$ & $<0.0001$ & $<0.0001$ & $<0.0001$ & - \\
\hline 15. & $\mathrm{Mg}$ & 0.01 & 0.19 & 0.24 & 0.16 & 0.18 & 0.12 & 0.15 \\
\hline 16. & $\mathrm{Mn}$ & 0.02 & 0.08 & 0.06 & 0.10 & 0.06 & 0.05 & 0.061 \\
\hline 17. & Mo & 1.41 & 0.77 & 1.19 & 0.28 & 1.82 & 1.64 & 1.185 \\
\hline 18. & $\mathrm{Ni}$ & 2.97 & 2.93 & 4.13 & 4.10 & 3.91 & 4.05 & 3.68 \\
\hline 19. & $\mathrm{Na}$ & 13.6 & 10.3 & 16.6 & 19.7 & 24.5 & 18.0 & 20.45 \\
\hline 20. & $P$ & $<0.018$ & $<0.018$ & $<0.018$ & 0.61 & 0.14 & 0.57 & 0.22 \\
\hline 21. & $\mathrm{~Pb}$ & 0.29 & 0.37 & 0.03 & 0.31 & 0.08 & 0.02 & 0.183 \\
\hline 22. & $\mathrm{Sb}$ & 1.09 & 2.97 & 2.57 & 2.04 & 1.64 & 2.65 & 2.16 \\
\hline 23. & Sc & $<0.0001$ & $<0.0001$ & $<0.0001$ & $<0.0001$ & $<0.0001$ & $<0.0001$ & - \\
\hline 24. & $\mathrm{Si}$ & 0.25 & 0.15 & 0.98 & 2.8 & 1.97 & 2.0 & 1.36 \\
\hline 25. & $\mathrm{Sr}$ & 0.16 & 0.10 & 0.11 & 0.31 & 0.56 & 1.17 & 0.40 \\
\hline 26. & $\mathrm{Ti}$ & $<0.0002$ & 0.01 & 0.07 & 0.74 & 0.1 & 0.2 & 0.18 \\
\hline 27. & V & 0.52 & 0.48 & 0.66 & 0.38 & 0.51 & 0.60 & 0.52 \\
\hline 28. & W & 4.69 & $<0.001$ & 6.0 & $<0.001$ & 6.21 & $<0.001$ & 2.82 \\
\hline 29. & $Y$ & $<0.001$ & $<0.001$ & $<0.001$ & 0.06 & $<0.001$ & $<0.001$ & 0.01 \\
\hline 30. & $\mathrm{Zn}$ & 1.68 & 7.37 & 4.83 & 0.36 & 1.78 & 2.04 & 3.01 \\
\hline 31. & Sn & 0.31 & 0.04 & 0.17 & 0.21 & 0.40 & 0.30 & 0.23 \\
\hline
\end{tabular}

Тамсагбулагийн XIX талбайн цооногуудын газрын тосонд тодорхойлсон микроэлементүүдийг харьцуулан харвал 21-р цооногийн газрын тосонд 
$\mathrm{Cu}, \mathrm{La}, 13-\mathrm{p}$ цооногийн газрын тосонд $\mathrm{Cd}, \mathrm{Pb}, \mathrm{Sb}, \mathrm{Zn}$ элементүүд, 25-50-р цооногийн газрын тосонд Ag, B, Ca, Mn, P, Si, Тi, Ү элементүүд, 40-р цооногийн газрын тосонд Al, Mo, Na, W, Sn элементүүд, 34-р цооногийн газрын тосонд $\mathrm{Ba}, \mathrm{Cr}, \mathrm{Fe}, \mathrm{Sr}$ зэрэг элементүүд тус тус хамгийн их илэрсэн байна.

Цагаан Элсний ордын газрын тосонд

3-р хүснэгт.

агуулагдах микроэлементийн дундаж агуулга, с.х

\begin{tabular}{|c|c|c|c|c|}
\hline \multirow{2}{*}{ № } & \multirow{2}{*}{ Элементүүд } & \multicolumn{2}{|c|}{ Цагаан Элсний орд } & \multirow{2}{*}{ Дундаж } \\
\hline & & TE 27-5-p & TE 14-19-p & \\
\hline 1. & $\mathrm{Ag}$ & 0.09 & 0.15 & 0.126 \\
\hline 2. & $\mathrm{Al}$ & 2.5 & 1.73 & 2.11 \\
\hline 3. & B & 1.54 & 4.82 & 3.18 \\
\hline 4. & $\mathrm{Ba}$ & $<0.004$ & 0.39 & 0.02 \\
\hline 5. & $\mathrm{Be}$ & 0.01 & $<0.001$ & 0.005 \\
\hline 6. & $\mathrm{Bi}$ & $<0.001$ & 0.03 & 0.015 \\
\hline 7. & $\mathrm{Ca}$ & 2.42 & 2.85 & 2.635 \\
\hline 8. & $\mathrm{Cd}$ & 0.34 & $<0.0001$ & 0.17 \\
\hline 9. & Co & 0.66 & 0.52 & 0.59 \\
\hline 10. & $\mathrm{Cr}$ & 0.91 & 1.15 & 1.03 \\
\hline 11. & $\mathrm{Cu}$ & 1.94 & 0.07 & 1.005 \\
\hline 12. & $\mathrm{Fe}$ & 2.15 & 2.85 & 2.5 \\
\hline 13. & La & $<0.001$ & $<0.001$ & - \\
\hline 14 & $\mathrm{Li}$ & $<0.0001$ & $<0.0001$ & - \\
\hline 15. & $\mathrm{Mg}$ & 0.24 & 1.98 & 1.11 \\
\hline 16. & $\mathrm{Mn}$ & 0.20 & 0.15 & 0.17 \\
\hline 17. & Mo & 0.34 & 0.75 & 0.54 \\
\hline 18. & $\mathrm{Ni}$ & 3.40 & 2.25 & 2.82 \\
\hline 19. & $\mathrm{Na}$ & 35.5 & 35.8 & 35.6 \\
\hline 20. & $P$ & 0.13 & $<0.018$ & 0.06 \\
\hline 21. & $\mathrm{~Pb}$ & 1.03 & 1.29 & 1.16 \\
\hline 22. & $\mathrm{Sb}$ & 2.36 & 3.09 & 2.72 \\
\hline 23. & Sc & 0.05 & 0.03 & 0.04 \\
\hline 24. & $\mathrm{Si}$ & 5.97 & 5.55 & 5.76 \\
\hline 25. & $\mathrm{Sr}$ & 1.79 & 3.07 & 2.43 \\
\hline 26. & $\mathrm{Ti}$ & 0.27 & 0.31 & 0.29 \\
\hline 27. & $\mathrm{~V}$ & 0.81 & 1.13 & 0.98 \\
\hline 28. & W & $<0.001$ & $<0.001$ & - \\
\hline
\end{tabular}




\begin{tabular}{|l|c|l|l|l|}
\hline 29. & $\mathrm{Y}$ & $\mathbf{0 . 0 8}$ & 0.07 & 0.07 \\
\hline 30. & $\mathrm{Zn}$ & 0.46 & $\mathbf{0 . 7 9}$ & 0.62 \\
\hline 31. & $\mathrm{Sn}$ & $\mathbf{0 . 8 9}$ & 0.54 & 0.71 \\
\hline
\end{tabular}

Цагаан Элсний ордын газрын тосонд тодорхойлсон микроэлементүүдийг харьцуулбал TE 27-5-р цооногийн газрын тосонд $\mathrm{Al}, \mathrm{Be}, \mathrm{Cd}, \mathrm{Co}, \mathrm{Cu}, \mathrm{Mn}, \mathrm{Ni}$, $\mathrm{P}, \mathrm{Sc}, \mathrm{Si}, \mathrm{V}, \mathrm{Y}, \mathrm{Sn}$ элементүүд, TE 14-19-р цооногийн газрын тосонд Ag, B, Ba, $\mathrm{Bi}, \mathrm{Ca}, \mathrm{Cr}, \mathrm{Fe}, \mathrm{Mg}$, Mo, Na, Pb, Sb, Sr, Ti, Zn элементүүд тус тус хамгийн их байна.

Судалгаанд авсан Тамсагбулагийн XIX талбайн газрын тосонд $\mathrm{Li}, \mathrm{Sc}$ элементүүд, Цагаан Элсний газрын тосонд La, Li, W зэрэг элементүүд тус тус илрээгүй байна. Харин натри нь хамгийн их 10.3-35.8 с.х байгаа нь гүний давсархаг ус газрын тостой шүргэлцсэнээс үүссэн. Дээрх хоёр ордын газрын тосонд агуулагдах микроэлементүүдийг өсөх дарааллаар нь байрлуулбал:

Тамсагбулагийн $\mathrm{XIX}$ талбайн хувьд $\mathrm{Na}>\mathrm{Ni}>\mathrm{B}>\mathrm{Zn}>\mathrm{W}>\mathrm{Sb}>\mathrm{Cd},>\mathrm{Si}>\mathrm{Ca}$ $>\mathrm{Cu}>\mathrm{Mo}>\mathrm{Cr}>\mathrm{Fe}>\mathrm{V}>\mathrm{Sn}>\mathrm{Sr}>\mathrm{Al}>\mathrm{P}>\mathrm{Bi}>\mathrm{Pb}>\mathrm{Ti}>\mathrm{Mg}>\mathrm{La}>\mathrm{Ag}>\mathrm{Co}>\mathrm{Mn}>\mathrm{Be}$ $>\mathrm{Ba}>\mathrm{Y}$,

Цагаан Элсний ордын хувьд $\mathrm{Na}>\mathrm{Si}>\mathrm{B}>\mathrm{Ni}>\mathrm{Sb}>\mathrm{Sn}>\mathrm{Ca}>\mathrm{Fe}>\mathrm{Sr}>\mathrm{Al}>\mathrm{Pb}$ $>\mathrm{Mg}>\mathrm{Cr}>\mathrm{Cu}>\mathrm{V}>\mathrm{Zn}>\mathrm{Co}>\mathrm{Mo}>\mathrm{Ti}>\mathrm{Ag}>\mathrm{Mn}>\mathrm{Y}>\mathrm{P}>\mathrm{Sc}>\mathrm{Ba}>\mathrm{Bi}>\mathrm{Be}$,

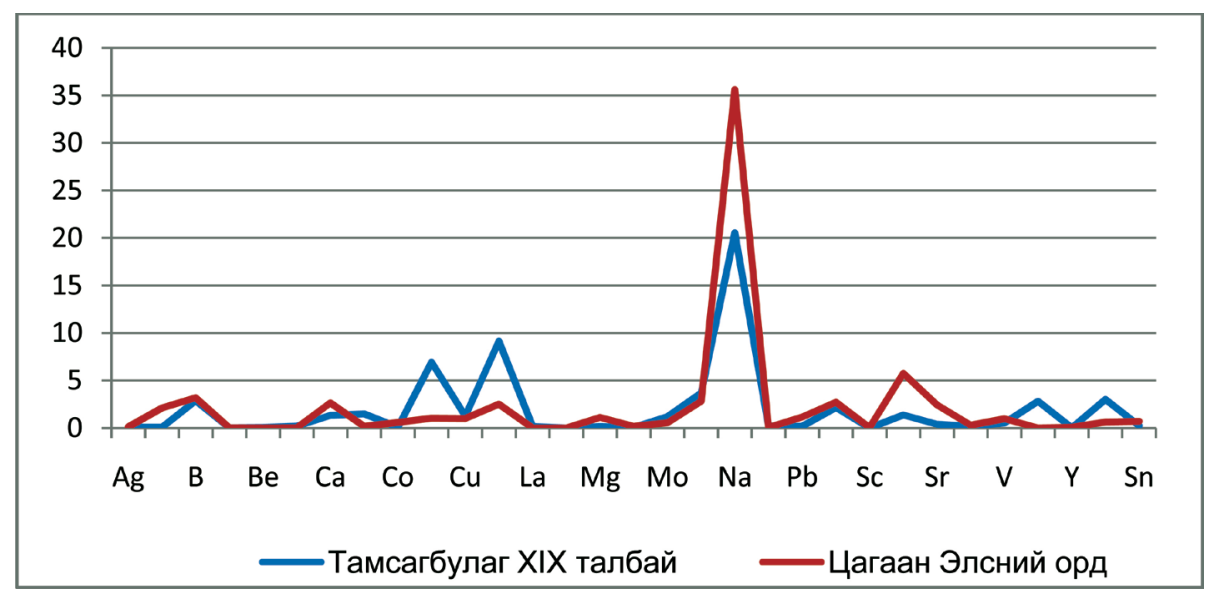

1-р график. Тамсагбулаг, Цагаан Элсний ордын газрын тосон агуулагдаж байгаа микроэлементүүдийн харьцуулалт

Дээрх харьцуулалтын графрикаас харахад $\mathrm{Be}, \mathrm{Bi}, \mathrm{Cd}, \mathrm{Mo}, \mathrm{Ni}, \mathrm{W}, \mathrm{Zn}$ зэрэг элементүүд Тамсагбулагийн газрын тосонд их, харин $\mathrm{Al}, \mathrm{Ca}, \mathrm{Co}, \mathrm{Fe}, \mathrm{Mg}, \mathrm{Mn}$, $\mathrm{Na}, \mathrm{Si}, \mathrm{Sr}, \mathrm{V}, \mathrm{Sn}$ зэрэг элементүүд нь Цагаан Элсний ордын газрын тосонд тус тус их байна. Өөрөөр хэлбэл газрын тосны нягт, хүхрийн агуулга ихсэхэд Al, $\mathrm{Ca}, \mathrm{Co}, \mathrm{Fe}, \mathrm{Mg}, \mathrm{Mn}, \mathrm{Na}, \mathrm{Si}, \mathrm{Sr}, \mathrm{V}, \mathrm{Sn}$ зэрэг элементүүдийн агуулга ихсэж Be, Bi, 
$\mathrm{Cd}, \mathrm{Mo}, \mathrm{Ni}, \mathrm{W}, \mathrm{Zn}$ элементүүдийн агуулга буурах гэсэн зүй тогтол ажиглагдаж байна.

Хүснэгт 2, 3-аас харахад Тамсагбулаг, Цагаан Элсний ордын газрын тосонд микроэлементүүд нь 0.001-35.8 c.x агуулгатай илэрсэн бөгөөд Li, V, $\mathrm{Sr}, \mathrm{Y}, \mathrm{La}, \mathrm{Sc}, \mathrm{Cd}, \mathrm{Be}, \mathrm{Bi}$, In зэрэг ховор элементүүд 0.03-3.07 c.x байгаа нь ховор элементийн түүхий эд болгон ашиглах боломжгүй юм.

Газрын тосонд агуулагдах зарим микроэлементүүдийн харьцааны коэффициентүүдийг ашиглан үүсэл гарлыг янз бүрээр тайлбарладаг $[13,17]$. Тодорхойлсон элементүүдээ ашиглан V:Ni, V/Fe, V/Mg, V/Cu, V/Cr, V/Zn, V:S коэфффициентүүдийг тооцоолон хүснэгт 4-д харуулав.

4-р хүснэгт,

Тамсагбулаг, Цагаан Элсний ордын газрын тосны V/Ni, V/Fe, V/Mg, V/Cu, V/Cr, V/Zn, V:S харьцааны коэфффициент

\begin{tabular}{|c|c|c|c|c|c|c|c|cc}
\hline \multirow{2}{*}{ № } & \multirow{2}{*}{ Коэфр. } & \multicolumn{7}{|c|}{ Тамсагбулагийн орд } & Цагаан Элсний орд \\
\cline { 3 - 10 } & $\begin{array}{c}21-\mathrm{p} \\
\text { цооног }\end{array}$ & $\begin{array}{c}13-\mathrm{p} \\
\text { цооног }\end{array}$ & $\begin{array}{c}25-50-\mathrm{p} \\
\text { цооног }\end{array}$ & $\begin{array}{c}\text { В-27-42-р } \\
\text { цооног }\end{array}$ & $\begin{array}{c}40-\mathrm{p} \\
\text { цооног }\end{array}$ & $\begin{array}{c}34-\mathrm{p} \\
\text { цооног }\end{array}$ & ТЕ 27-5-p & ТЕ 14-19-р \\
\hline 1. & $\mathrm{V} / \mathrm{Ni}$ & 0.17 & 0.16 & 0.16 & 0.09 & 0.13 & 0.15 & 0.23 & 0.50 \\
\hline 2. & $\mathrm{~V} / \mathrm{Fe}$ & 0.57 & 1.03 & 0.62 & 0.30 & 1.02 & 0.46 & 0.37 & 0.39 \\
\hline 3. & $\mathrm{~V} / \mathrm{Mg}$ & 52 & 2.52 & 2.75 & 2.37 & 2.83 & 5.0 & 3.37 & 0.57 \\
\hline 4. & $\mathrm{~V} / \mathrm{Cu}$ & 0.18 & 0.47 & 0.42 & 38 & 0.24 & - & 0.41 & 16.14 \\
\hline 5. & $\mathrm{~V} / \mathrm{Cr}$ & 1.62 & 0.44 & 0.52 & 0.32 & 0.55 & 0.27 & 0.89 & 0.98 \\
\hline 6. & $\mathrm{~V} / \mathrm{Zn}$ & 0.30 & 0.06 & 0.13 & 1.05 & - & - & 1.76 & 1.14 \\
\hline 7. & $\mathrm{~V} / \mathrm{S}$ & $3.19^{*} 10^{-4}$ & $2.69^{*} 10^{-4}$ & $4.2^{*} 10^{-4}$ & $3.11^{*} 10^{-4}$ & $3.26^{*} 10^{-4}$ & $5.30^{*} 10^{-4}$ & $3.36^{*} 10^{-5}$ & $6.10^{*} 10^{-5}$ \\
\hline
\end{tabular}

Хүснэгт 4-өөс харахад V:Ni-ийн харьцаа нь Тамсагбулаг, Цагаан Элсний ордын газрын тосны хувьд 0.09-0.50 байгаа нь мезозойн болон гуравдагч үеийн насжилттай чулуулагт агуулагдах газрын тос байж болох юм [17].

\section{дүгнЭлт}

1. Вe, Bi, Cd, Mo, Ni, W, Zn зэрэг элементүүд Тамсагбулагийн газрын тосонд их харин Al, Ca, Co, Fe, In, Mg, Mn, Na, Si, Sr, V, Sn зэрэг элементүүд нь Цагаан Элсний ордын газрын тосонд тус тус их байна. Өөрөөр хэлбэл газрын тосны нягт, хүхрийн агуулга ихсэхэд Al, Ca, Co, Fe, In, Mg, Mn, Na, Si, Sr, V, Sn зэрэг элементүүдийн агуулга ихэсдэг гэсэн зүй тогтол ажиглагдаж байна.

2. Тамсагбулаг, Цагаан Элсний ордын газрын тосонд микроэлементүүд нь 0.001-35.8 с.х агуулгатай илэрсэн бөгөөд Li, V, Sr, Y, La, Sc, Cd, Be, Bi, In зэрэг ховор элементүүд 0.03-3.07 с.х байгаа нь ховор элементийн түүхий эд болгон ашиглах боломжгүй юм.

3. V:Ni-ийн харьцаа нь Тамсагбулаг, Цагаан Элсний ордын газрын тосны хувьд 0.09-0.50 байгаа нь мезозойн болон гуравдагч үеийн насжилттай чулуулагт агуулагдах газрын тос байж болох юм. 


\section{АШИГЛАСАН МАТЕРИАЛ}

1. Мөнхжаргал.Б, Нордов.Э. Монголын газрын тосны химийн судалгааны өнөөгийн байдал. Монгол орны газрын тосны хими технологийн судалгаа. УБ 2004, х.76.

2. Калинин.Е.П. Геохимическая специфика нефти и ее природа. Вестник, январь, 2009 г., № 1. с.6-12.

3. Сюняева 3.И. Химия нефти. Л., Химия 1984. С.297-313.

4. Монхообор.Д. Нефтийн хими. УБ 2003. Х 22-25.

5. James.G.S. Petroleum Chemistry and Refining. 19986 p.48-50.

6. John.S.B, Wenger.J.W Metal content of Twenty-four petroleums. Journal of Chemical and Engineering data. Vol 5. №4, October 1960. p 553-557.

7. Сайнбаяр.Ж, Есетжан.А, Төгсөө.Ц, Сүхдорж.Г, Монхообор.Д. Тамсагбулагийн газрын тосны ванади, никелийг спектроскопийн аргаар судлах нь. ШУА-ийн мэдээ. 2009. №02, х.37-45

8. Royston.H.F, Gary.J.V.B. Geochemistry of Metal Complexes in Petroleum, Source Rocks and Coals. American Chemical Society. 1987. p.2-16.

9. Гожик.П.Ф, Краюшкин.В.А, Клочко.В.П, Гусева.Э.Е, Морозова.Р.М. Ванадий и никель в природных нефтях Азии, Африки, Европы, Северной и Южной Америки. Доповіді Національноі академіі наук Украіни. 2007. №3. с.137-141.

10. Колодчжный.А.В,Ковальчук.Т.Н, Коровин.Ю.В, Антонович.В.П. Определение микроэлементного состава нефтей и нефтепродуктов. Состояние и проблемы. Методы и объекты химического анализа. 2006.T.1. №2. c.900-104.

11. Слотвинский-Сидак Н.П, Андреев В.К. Ванадий в природе и технике. Москва, 1979. с10-24.

12. Якуцени.С.П. Экологические проблемы при освоении и разработке нефтяных месторождений. Геология нефтти и газа. №01. 2000. с.34-40.

13. Mohammad.F, Ahmed.B, Mohammad.S.Trace Metals in Crude Oils from Saudi Arabia. Ind. Eng. Chem. Pro. Res. Pev. 1983, 22, p.691-694.

14. ASTM D5185-02e2. Standard Test Method for Determination of Additive Elements, Wear Metals and Contaminants in Used Lubricating Oils and Determination Selected Elements in Base oils by Inductively Coupled Plasma Atomic Emission Spectrometry.

15. Бухбиндер.Г.Л, Шабанова.Л.Н, Гильберт.Э.Н. Определение микроэлементов в нефти атомно-эмиссионным методом с индуктивносвязанной плазмой. Журнал аналитической химии.Tом XLIII. 1988. c.1323-1329,

16. Plasma Optical Emission Spectrometry 1999 in U.S.A.

17. Салимов.М. Тяжелые нефти и природный битум хорошо забытое старое сырье. $h$ ttp://msalimov.narod.ru/Vanad.html.

18. Рюмин А.А, Копяткевич М.С, Грибков В.В. О типизации ванадиеносных нефтей. Геология нефти и газа №06, 1989. 